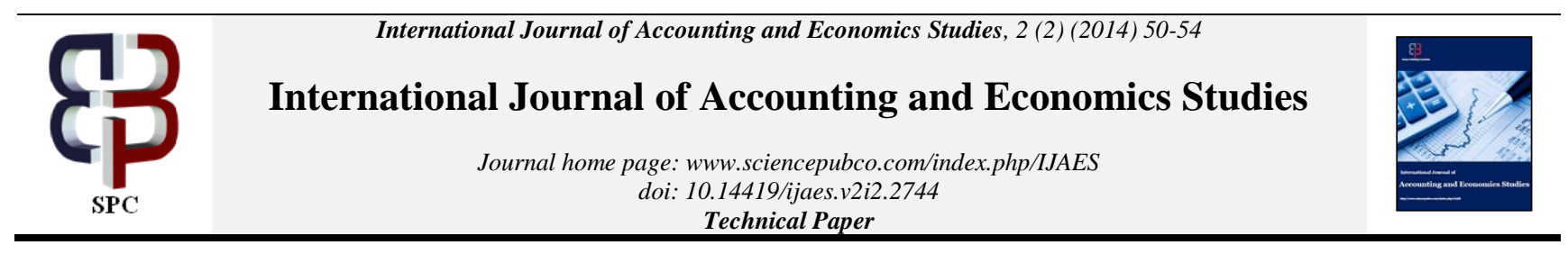

\title{
Backed and unbacked central bank money
}

\author{
Romar Correa \\ Department of Economics, University of Mumbai, Mumbai 400 098, India \\ E-mail: romarcorrea10@gmail.com
}

\begin{abstract}
Fiat money, by connotation of the term, does not require the backing of goods or assets. At the same time, chartalists and others argue that government money comes into existence along with government taxation. A corollary must be that if, in keeping with the zeitgeist, direct taxes converge to zero, Central Bank money must vanish. Put differently, if the budget is balanced, the government, along with its monopoly of note issue, ceases to be of interest.

The case for competitive currencies lies here. Add to it the demise of banking in the traditional sense and the ascendance of financial institutions with universal functions. In a competitive economy buzzing with current activity and plans for future activity, the intrusion of government in the senses above cannot be welfare-enhancing.

The press for free banking becomes muted in times of crisis. Indeed, in the aftermath of the financial-real meltdown in America, the Federal Reserve began to operate on the long end of the term structure of interest rates, the portion of the yield curve believed to be determined by private investment plans.

We examine these different institutional arrangements along a causal dimension. For the purpose, we build up consistent accounting structures. The objective is to appraise the systemic stability of various monetary arrangements.

Keywords: Private Money; Government Money.
\end{abstract}

\section{Introduction}

Money is introduced by fiat in mainstream economics like the overlapping generations model in order to effect trade. The alternative is autarky. Since fiat money is intrinsically worthless, it is imperative that all agents believe that it has positive value for all time to come. In neoclassical economics these tokens then do not merit further attention. The analytical focus is on (shocks to) preferences and technology. Indeed, it does not matter whether there is a Central Bank (CB) that provides the medium of exchange and store of value or competitive issuers of currency that enjoy credibility and reputation emerge from the private enterprise economy. On the other hand, fiat money in history seems to have been backed. For example, the fiat paper money emissions in British North America linked future redemptions to taxes that could be paid through the emissions (Grubb 2012). The equation of bills with their removal from circulation through local tax payments anchored the value of paper money to a real value. When the current spending of a colonial government exceeded its current tax receipts, it would borrow from its subjects in the form of "bills of credit". The bills could be used to pay future taxes. In other words, they were bearer bonds and could be regarded as inside money or a medium of exchange.

All the same, the origins of money in history are contentious. On the one hand, advocates of free banking and private note issue record that regions of the world enjoyed epochs of relative stability thanks to multiple currencies issued locally. Even sensitive Post Keynesians cannot dismiss the nice properties of aeons of private monies (Palley 2014). It cannot be doubted that the arrival of CBs on the world stage is relatively recent. Usually, their entry was heralded by wars or natural calamities. The Bank of England,
(BoE), established in 1694, for example, was born in war. In an era of specie money, the war finances came from investors in the joint-stock bank (Nacaskul et al. 2012). The BoE was not a source of funds but an intermediary between the government and financial investors. Through a special charter, it underwrote the credit risk of the government. As another illustration, in one reflection on the past, it is claimed that if a CB existed, the distress caused by crop failures in America would have been ameliorated (Hanes $\&$ Rhode 2012). There were five national crises in gold-standard America during 1879-1913. Fluctuations in cotton harvests had a role to play. A Fed, through OMOs as well as financial institutional balances with it, would have affected the supply of non-gold high-powered money and counteracted the financial repercussions of these movements. In other scenarios, when private enterprise was not up to the task of post-war reconstruction efforts, governments had to institutionalise 'their' banks to address the scale of activity. To generalise, the development of capitalism was supported by governments. One macroeconomic arm is the $\mathrm{CB}$, the other the fiscal authorities. Thus, the story of modern money, in this view, is effectively the emergence of CB money.

We examine different monetary configurations in logical time. For the purpose, we use the stock-flow-consistent macroeconomics of Godley and Lavoie (2007). Use will be made of the definition that a flow is a change in a stock. The principle is to look at the economy as a matrix and the cross-checks are the discipline of doubleentry bookkeeping. Rows and columns entries must sum to zero. The account below is innocent of behavioural foundations. Instead, in the style of twentieth-century macroeconomics, we will operate with a clutch of ratios, not excluding the classic Kaldor evaluation ratio. Their attraction is that they are engaging the attention of academics and policy makers the world over. 


\section{A private money economy}

The box below is pared down to the essentials to capture the essence of an economy that does not require government money. The notations are introduced with the concepts and are familiar from any introductory economics text. Note that the interrelatedness of rows and columns originates with the autonomous investment plans of firms. Banks come into play to support their plans. This observation supports the Keynes-Schumpeter primacy attached to business behaviour as against the neoclassical sequence that would originate with the savings of workers-consumers in banks. Profits, $\mathrm{F}_{\mathrm{f}}$, are also an important driver of the system. Some portion, $\mathrm{FD}_{\mathrm{f}}$, is distributed to shareholders; the remainder, $\mathrm{FU}_{\mathrm{f}}$, is retained to finance future investment plans. Identical remarks apply to profit-maximizing banks.

If we were to regard the box as the national income accounts of a country, it is possible that all the elements are working at the preferences-technological frontier. Also, it is likely that large components in the aggregate investment entry represent the activity of public sector firms. Government investments play a pivotal role in any economy. If, indeed, the entries in the matrix are shrunken, in keeping with a recession, it is only government investment that can enlarge them. Keynes' "socialization of investment" is recalled here. He proposed that large indivisible projects entailed incalculable uncertainties and, consequently, private investments might not be forthcoming. Only governments can assume these massive risks

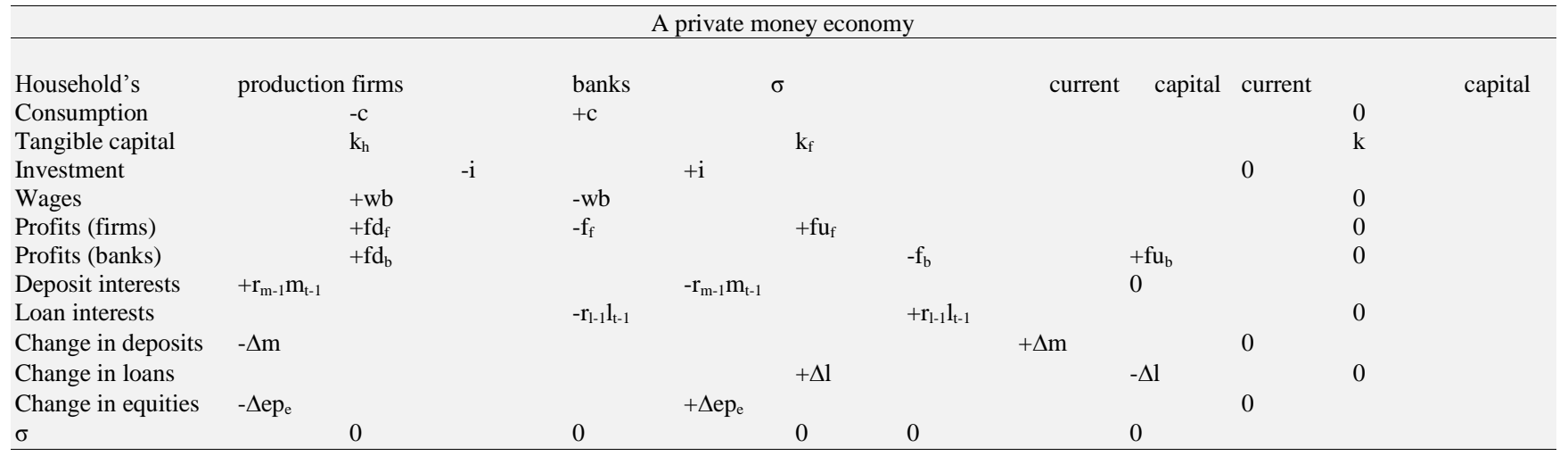

Using the notation, $\Delta \mathrm{X} \equiv \mathrm{X}_{\mathrm{t}}-\mathrm{X}_{\mathrm{t}-1}$, we can derive the balance sheet of this transactions matrix. The latter, with the change in the values of the stocks, is based on a unit of time. If, on the other hand, we are interested in a snapshot of the economy at a point of time, only the levels of the variables matter. The steady state of the system is given by both the interest rates being equal to zero. A null rate of interest is also the solution in any standard general equilibrium model.

A unit of account would be needed for wage payments to be made and for consumption bills to be paid. The classical economists recorded numerous monetary mechanisms devised by society to solve the problem of the absence of the double coincidence of wants. From the present, general equilibrium theory can be used to study the novel experience of electronic money in Kenya (Jack et al. 2010). In 2007, a cell phone company Safaricom Limited, launched M-PESA, an SMS-based money transfer system to deposit, send and withdraw funds from a virtual account from the banking system. E-money peacefully coexists with fiat money. It meets, with outstanding success, the means of exchange and store of value functions of money. In economies with this mix, crosssectional data shows that as per capita national income increases or financial interconnectedness increases, fiat money decreases and per capita private debt increases. The ratio of fiat money to income decreases and the ratio of credit to income increases. There are no interest rates but charges deducted from the users' costs when e-money is sent or when it is withdrawn. The fees include the costs of maintaining and expanding the agent network and physical infrastructure, marketing and profits. The marginal cost of depositing and sending money is low. The commodity emoney is measured in the same units as fiat money. Redolent of the Walrasian programme, in the equilibrium of the e-money economy, fiat money plays no role. An arbitrary unit of account will suffice to express the prices of goods.

The phenomenon of null interest rates along with zero investment in equilibrium leads to the current interest in Islamic finance (Sheng \& Singh 2012). Zero interest rates were foreshadowed in the seminal contributions of Pigou and Patinkin where positive interest rates favoured current generations over future generations. Later, Keynes needed zero interest rates in the General Theory to establish continuous full employment in his model. Consistent with the above balance sheet, Islamic laws encourage zero interest rates and the continuous circulation of money (wages in our model) for the purpose of consumption. How is capital accumulation to be induced? The Islamic economy is one in which capital is rewarded according to its earning capacity. The rate of return is determined ex post, based on the actual return in the economy. There is no notion of an ex ante rate of return as given in our box. In like manner, depositors do not earn interest but are shareholders in the bank. They earn a share of the profits in this equity-based system. In addition, the risks that future generations would face are shared by the present generations through rules of inheritance. Accordingly, accumulated wealth is broken up as it is bequeathed, thereby enabling a larger mass of the populace to be insured against risks.

Out of the long run, it turns out that the stock market rather than banks are essential to capturing the accumulation of capital in this economy. The three important ratios for a private sector economy are as follows. The dividend yield of firms, $r_{K}=F D / e_{t-1} p_{t-1}$; the price earnings ratio, $\mathrm{PE}$, defined as $\mathrm{p}_{\mathrm{e}} \mathrm{e}_{\mathrm{t}-1} / \mathrm{F}_{\mathrm{f}}$; Tobin's $\mathrm{q}=\left(\mathrm{e}_{\mathrm{t}} \mathrm{p}_{\mathrm{t}}+\right.$ $\mathrm{L}) / \mathrm{K}$. Expressing components of the matrix in equation form, investments plans, I, are financed by some combination of the issue of new shares, $\Delta \mathrm{ep}_{\mathrm{e}}$, new contracts struck with bank managers, $\Delta \mathrm{L}$, and profits undistributed from the last period, $\mathrm{FU}$. That is, $\Delta \mathrm{ep}_{\mathrm{e}}=\mathrm{I}-\Delta \mathrm{L}-\mathrm{FU}$

Using the three ratios introduced, and recalling the definition $\mathrm{F}_{\mathrm{f}}=$ $\mathrm{FD}_{\mathrm{f}}+\mathrm{FU}_{\mathrm{f}}$

$\Delta \mathrm{ep}_{\mathrm{e}}=\mathrm{I}-\mathrm{qK}+\Delta \mathrm{e} \Delta \mathrm{p}_{\mathrm{e}}-\mathrm{p}_{\mathrm{e}} \mathrm{e}_{\mathrm{t}-1} / \mathrm{PE}+\mathrm{r}_{\mathrm{K}} \mathrm{e}_{\mathrm{t}-1} \mathrm{p}_{\mathrm{et}-1}$

Simplifying, according to our notations,

$(1 / P E-1) p_{e} e_{t-1}=I-q K-\left(1-r_{K}\right) p_{e t-1} e_{t-1}$

If we assume an unchanged price of equities,

$\left(1 / \mathrm{PE}-\mathrm{r}_{\mathrm{K}}\right)=\mathrm{I}-\mathrm{qK}$

Consequently, the requirement is $1 / \mathrm{PE}>\mathrm{r}_{\mathrm{K}}$.

If we assume away the time subscripts in the components of this inequality, we get the condition $\mathrm{FD} / \mathrm{F}<1$. In other words, the plough back of profits is fundamental to a system that also finances investment by recourse to fresh equity of shares and loans from banks. The contrast with dividend distribution maximization behaviour typical of modern corporations is sharp. 


\section{An economy with government money}

\subsection{Steady state budget deficits}

The introduction of government is accomplished below by the appropriate extension of our chart. Some of the harmless simplifications we will continue with is that only firms take loans as does the government 'morally persuade' banks to hold short-term paper. A change in the monetary base appears identically to bill financing of the government deficit. When a CB makes loans or purchases assets, it alters the total supply of credit by the amount of the loan or asset purchase. The contribution of a CB to the total supply of credit is given by the size of its balance sheet or the size of the adjusted monetary base. Its contribution to the supply of credit is smaller than its contribution to the supply of money be- cause of the fractional reserve system. Once again, just a visual check will establish that government expenditure is 'autonomous' to the system. In particular, during periods of depressed activity it can generate current employment not by paying wages to dig holes in the ground but by incurring expenditures to build roads and dams and so on. The potentially large $G$ here is the hallmark of the Eisenhower budgets that resulted in the interstate road network in the US after the War. Post Keynesians reverse the causal arrow from tax receipts to government spending. The proposition is that the government spends its money into existence (Wray 2012). Keystrokes credit bank reserves with banks crediting the accounts of the recipients. According to the definition of high-powered money, taxes are paid for by customers who debit their accounts with their banks. In short, fiat money is the "means of tax settlement". Note that by our accounting principle the entries for both the fisc and the CB sum to zero.

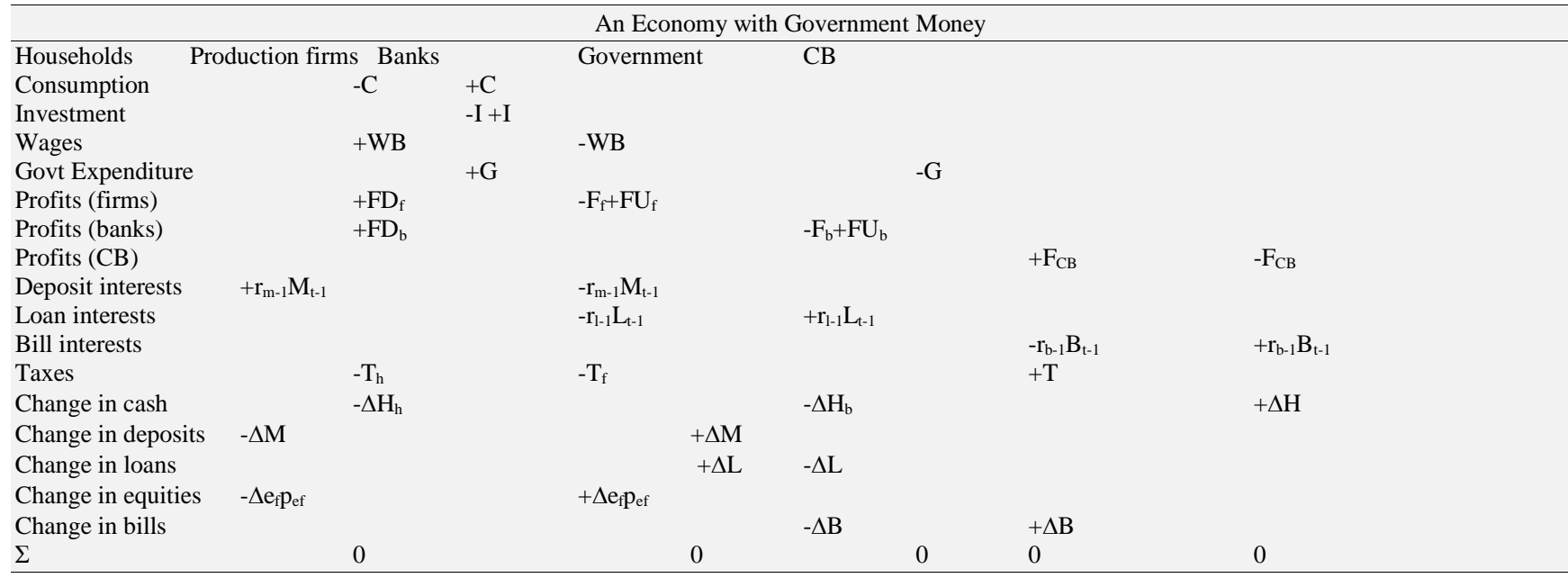

The expressions that are on the radar of the economic policy establishment all over the world is the capital adequacy ratio CAR = $\mathrm{M} / \mathrm{L}$ and the bank liquidity ratio, BLR $=\mathrm{B}_{\mathrm{b}} / \mathrm{M}$. Instead of deposits, we might entertain financial institutions with own equity as a substitute. Nothing changes. Indeed, in the case of exclusive money-financing of the deficit, $\mathrm{B}_{\mathrm{b}}$ becomes $\mathrm{H}$, high-powered money and, instead of BLR, we would have the cash reserves ratio.

Now, an elementary bank balance sheet that can be derived is

$\mathrm{L}+\mathrm{B}_{\mathrm{b}}=\mathrm{M}$

Using the definitions, the requirement of the system is

$1 / \mathrm{CAR}+\mathrm{BLR}=1$

These formulae are associated with Basel norms and have been criticised on various grounds. For one, they are 'one-size-fits-all' and cannot be adapted to the idiosyncratic requirements of specific economies. On the other hand, our ratios emerge endogenously and can be the outcome of dialogue between the various classes behind the social accounting matrices. A second charge against Basel norms is that they are procyclical. Our ratios, on the other hand, figure in structural equations that include economy-wide variables. They can be calibrated to the nuances of the dynamics of particular economies.

\subsection{Cash transfers}

Subsidies and cash transfers are taxes with a change in sign. Indirect taxes become subsidies and direct taxes are transformed into cash transfers. Both items are a matter of active, though independent, debate in developing countries. Subsidy bills are widely believed to be outcome-inefficient. In their place, a regime of direct cash transfers is recommended. Cash transfers have been extensively employed in many continents. The programmes the world over have certain common features of relevance to our discussion (Cortés \& Rubalcav 2012, Latapi 2012, Soares 2012). In the first place, they are clearly the business of the central government. It is worth noting, as in the case of the birth of CB money, the oportunidades programme in Mexico was the brainchild of the government that came into existence after the economic crisis in December 1994. There was a debate between providing cash or the traditional goods and services. The scheme uses "proxy means testing' while the Bolsa Familia's targeting mechanism in Brazil is based on 'means testing' which is self-reporting of income. The transfer of cash between the government and the oportunidades beneficiaries is unmediated. The lack of community participation is regarded as a shortcoming by Bryan Roberts (2012) but it is precisely anonymity that characterises CB money.

The dynamics of the economy is determined by cash and the bill market. In the steady state, once more, $r_{b}=0$. The scenario underplays many national money markets where banks, on the margin, have preferred to invest in government paper rather than plant and machinery. The $\mathrm{CB}$ would enter the scheme as the residual holder of the government paper. Close cooperation between the $\mathrm{CB}$ and the commercial banking system is entailed. In addition, it is only in the case of a model with one target, inflation, that the case for an independent $\mathrm{CB}$ can be made. Here, the monetary and the fiscal authorities are joined by identities (Cobham 2012). In addition to the ones cited, CB profits, we know are transferred to the Treasury. This means that the government's interest payments on its debt held by the CB are returned to the government. That is, the net debt service cost on that debt is zero. The old "fiscal finance" case for independent CBs was made in the context of banks that were chartered to make profits on the issue of bank notes in exchange for lending to governments. Marvin Goodfriend (2012) has advised adherence to "Treasuries only" asset acquisition so as to avoid credit risk on the $\mathrm{CB}$ balance sheet. A CB would then transfer all net interest income to the fiscal authorities. 


\subsection{Government bonds}

The interventions of the US Fed post crisis have been interpreted as a rediscovery of the long-term bond as an instrument of policy. The universal understanding has been that CBs operate with a short-term rate like the Federal funds rate leaving the long rate to be determined by the market. Of course, CBs seek to manipulate the connection between the two, the yield curve. The difference between bills and bonds is capital gains. Whereas bills have a finite life and are extinguished, bonds are perpetuities. In addition, it is claimed that the lender-of-last-resort facility was not just about injecting liquidity into the banking sector but also about operations in the bond market (de Grauwe 2013). In the background was the "deadly embrace' between the sovereign and banks. When the sovereign faced debt problems, banks would be jeopardised by the collapsing bond market because they were the main holders of the debt. In this connection, it is worth observing the famous maturity mismatch that describes banks are mirrored in the government balance sheet. The liabilities are liquid like bonds while assets are infrastructure and tax claims. Recently, a change in the relation between the federal funds rate and the ten-year treasury yield has been noticed. According to one opinion, the transformation occurred because the FOMC began using the former as a policy target rather than an operating target (Thornton 2012a). In that case, eventually Goodhart's Law kicks in: Any observed statistical regularity will tend to unravel as it is exploited for policy purposes. The Federal Reserve has pioneered so-called "forward guidance" by committing to a policy rate for an indefinite period of time, thereby reducing the long-term rate (Thornton 2012b). Secondly, in what has been termed "operation twist" (of the yield curve), it reduced the long rate by purchasing long-term securities, simultaneously selling an equivalent amount of shortterm securities, thereby leaving the total supply of credit unchanged. Our balance sheet, simplified to include this item, is as follows.

\begin{tabular}{|c|c|c|c|c|c|c|c|c|c|}
\hline \multicolumn{10}{|c|}{ An economy with government bonds } \\
\hline Household's & firms & & gov & & central bank & & $\sigma$ & & \\
\hline Consumption & & $-\mathrm{c}$ & & $+\mathrm{c}$ & & & & & 0 \\
\hline govt expenditures & & & $+g$ & & $-\mathrm{g}$ & & & 0 & \\
\hline Income & & $+\mathrm{y}$ & & $-\mathrm{y}$ & & & & & 0 \\
\hline Bill interests & & & & & $-r_{b-1} b_{t-1}$ & & $+\mathrm{r}_{\mathrm{b}-1} \mathrm{~b}_{\mathrm{t}-1}$ & & \\
\hline Bond interests & & $+\mathrm{bl}_{\mathrm{t}-1}$ & & & $-b \mathrm{l}_{\mathrm{t}-1}$ & & & & 0 \\
\hline cb profits & & & & & $+\mathrm{r}_{\mathrm{b}-1} \mathrm{~b}_{\mathrm{t}-1}$ & $-r_{b-1} b_{t-1}$ & & 0 & \\
\hline Taxes & & $-t_{h}$ & & $-t_{f}$ & $+\mathrm{t}$ & & & & 0 \\
\hline Changes in money & $-\Delta \mathrm{h}$ & & & & & $+\Delta \mathrm{h}$ & & 0 & \\
\hline Changes in bills & & & & & $-\Delta b$ & & $+\Delta \mathrm{b}$ & & 0 \\
\hline $\begin{array}{l}\text { Changes in bonds } \\
\sigma\end{array}$ & $-\Delta \mathrm{blp}_{\mathrm{bl}}$ & 0 & 0 & & $+\Delta \mathrm{blp}_{\mathrm{bl}}$ & & 0 & 0 & \\
\hline
\end{tabular}

In elaborations of this institutional scenario, some scholars have recommended the formation of corporations of bondholders (Flandreau 2013). Committees of bondholders might threaten to withhold further credit. Governments, who were in default on their obligations and who refused to negotiate in good faith with their creditors, could be denied new loans. Once again, we assume, without loss of generalisation, that only households hold government bonds. CBs can expect to unload their holdings of government bonds back into the market once the economy has revived and interest rates have risen to conventional levels. They are guaranteed against capital losses by their Treasuries. We offer an anchor here for the degree of maturity of the long-term instrument and the agency that provides it which neoclassical theory does not provide (Turner 2012). Indeed, the uncertainty about the connection between the bank rate and the long-term rate can be traced to the deliberations around the Radcliffe Report of 1959. The early case for operations in the bond market was, in other words, instrument uncertainty, and the lack of knowledge about the impact on interest rates of changes in the policy rate. OMOs, it was felt, would be countercyclical monetary policy proper, as they would shift the whole yield curve. The dynamics here involves a price, the rate of return on the government bond. Since the primary issue of bonds is the sine qua non of government activity in this model, we need to pin down the price of bonds. Fortunately, the identities can be manipulated to provide just such a policy measure naturally. Godley \& Lavoie exploit the following identity in this instance. Mimicking the calculus breakup in continuous time, the change in the value of the bonds can be broken into two parts,

$\Delta \mathrm{BL} \Delta \mathrm{p}_{\mathrm{bL}}=\mathrm{BL} \Delta \mathrm{p}_{\mathrm{bL}}+\mathrm{BL} \Delta \mathrm{p}_{\mathrm{bL}}$

The latter expression on the right-hand side is capital gains and is the only concept that has an impact on our model. In what is called Haig-Simons income, to the disposable income of households, $\mathrm{YD}$, capital gains are added. Thus,

$\mathrm{YD}_{\mathrm{HS}}=\mathrm{YD}+\Delta \mathrm{p}_{\mathrm{bL}} \mathrm{BL}$

That is to say, absent this term, we return to the origins of the long-term bond as being $\mathrm{CB}$ money.

\section{Conclusion}

As the demands of a private economy arise, purveyors of money will emerge to smoothen the flow of goods and services. These financial intermediaries can create markets for consumption and production across time and space. Since their origins will be local communities, problems of asymmetric information might not arise. When it comes to financing new investments, innovations and the like, market funding will the paramount mode of financing. However, it remains true that, in the absence of solid support provided by the State, these economies experience violent fluctuations in activity. Central Banks emerge from the community of banks and, consequently, when monetary and fiscal policies are incisive, they must be affected through the medium of commercial banks. Here, as well, behaviour might go out of stabilizing ratios. The international community, through Basel norms, has provided a variety of speedbreakers so as to mitigate the severity of these cycles. Secondly, one lesson of history has been that the scale of operation of private economies is small. Once the engine of capitalism was in full throttle, both what Hyman Minsky called the "big bank" and "big government" were called upon. The latter suggests that the large government expenditures that are called upon be matched by large taxation of the identical magnitude. In the case of a discrepancy between the two, under normal circumstances when the $\mathrm{CB}$ operates on an overnight rate, the dynamics of the bill market subsumes everything else. On the other hand, if the $\mathrm{CB}$ of the future is to bend the yield curve from the long end, it will have to pin down the long rate from the arithmetic of macroeconomic identities.

\section{References}

[1] Cobham D (2012) The past, present and future of central banking, Heriot-Watt University Economics Department Working Paper No.2012-05, November 2012 
[2] Cortés F \& Rubalcav RM (2012) PROGRESA as a Response to the 1994 Crisis, UNDP International Policy Centre for Inclusive Growth, one-pager No.169.

[3] De Grauwe P (2013) Design Failures in the Eurozone: Can they be fixed? LSE 'Europe in Question' Discussion Paper No. 57/2013, February 2013

[4] Flandreau M (2013) Collective Action Clauses before they had Airplanes: Bondholder Committees and the London Stock Exchange in the $19^{\text {th }}$ century (1827-1868), Graduate Institute of International Development Studies Working Paper No. 01/20123, January 2013.

[5] Godley W \& Lavoie M (2007) Monetary Economics. Hampshire, Palgrave Macmillan.

[6] Goodfriend M (2012) The Elusive Promise of Independent Central Banking, Bank of Japan, Institute of Monetary and Economic Studies (IMES), Discussion Paper No.2012-E-9.

[7] Grubb F (2012) Is Paper Money Just Paper Money? Experimentation and Local Variation in the First Paper Monies Issued by the Colonial Governments of British North America, 1690-1775, Part I, University of Delaware, Alfred Lerner College of Business and Economics, Department of Economics Working Paper No. 2012-07.

[8] Hanes C \& Rhode PW 2012, Harvests and Financial Crises in GoldStandard America, NBER Working Paper 18616, December 2012.

[9] Jack W, Suri T \& Townsend R (2012) Monetary Theory and Electronic Money: Reflections on the Kenyan Experience, Federal Bank of Richmond Economic Quarterly 96, 83-122.

[10]Latapi AE (2012) Public Policy and Society: Two Essential Mediating Factors for Conditional Transfer Programmes, UNDP International Policy Centre for Inclusive Growth, one-pager No.171.

[11]Nacaskul P, Janjaroen K \&, Suwanik S (2012) Economic Rationale for Central Banking: Policy Space, Institutional Integrity, and Paradigm Challenges, Bank of Thailand Discussion Paper 04/2012.

[12]Palley T (2014) Modern Money Theory (MMT): the emperor still has no clothes, February 2014

[13]Roberts B (2012) From Universalism to Targeting and Back Again Conditional Cash Transfers and the Development of Social Citizenship, International Policy Centre for Inclusive Growth, one-pager No. 178.

[14]Sheng A \& Singh A (2012) Islamic finance revisited: conceptual and analytical issues from the perspective of conventional economics, University of Cambridge, CBR Working Paper 2012, 1-35.

[15] Soares FV (2012) Oportunidades and Bolsa Familia: A Comparative Perspective of their Evolution, UNDP International Policy Centre for Inclusive Growth, one-pager No.177.

[16]Thornton DL (2012a) Greenspan's Conundrum and the Fed's Ability to Affect Long-Term Yields, Research Division, Federal Reserve Bank of St Louis Working Paper 2012-036A, September 2012

[17](2012b) The Federal Reserve's Response to the Financial Crisis: What it did and What It Should Have Done, Research Division, Federal Reserve Bank of St Louis Working Paper 2012-050A, October 2012.

[18]Turner P (2012) Benign neglect of the long-term interest rate, BOS Working Paper No.403.

[19]Wray LR (2012) A Meme for Money, Levy Economics Institute of Bard College Working Paper No. 736, November 2012. 